\title{
Servant Leadership Attributes and Employee Performance among Support Staff in A Malaysian Private University
}

Tak Jie Chan, Nur Amalia Rahwani Abd Rahim, Saodah Wok

To Link this Article: http://dx.doi.org/10.6007/IJARBSS/v11-i2/8467

DOI:10.6007/IJARBSS/v11-i2/8467

Received: 17 December 2020, Revised: 14 January 2021, Accepted: 31 January 2021

Published Online: 24 February 2021

In-Text Citation: (Chan et al., 2021)

To Cite this Article: Chan, T. J., Abd Rahim, N. A. R., \& Wok, S. (2021). Servant Leadership Attributes and Employee Performance among Support Staff in A Malaysian Private University. International Journal of Academic Research in Business and Social Sciences, 11(2), 362-384.

\section{Copyright: (c) 2021 The Author(s)}

Published by Human Resource Management Academic Research Society (www.hrmars.com)

This article is published under the Creative Commons Attribution (CC BY 4.0) license. Anyone may reproduce, distribute, translate and create derivative works of this article (for both commercial and non-commercial purposes), subject to full attribution to the original publication and authors. The full terms of this license may be seen at: http://creativecommons.org/licences/by/4.0/legalcode

Vol. 11, No. 2, 2021, Pg. 362 - 384

Full Terms \& Conditions of access and use can be found at http://hrmars.com/index.php/pages/detail/publication-ethics 


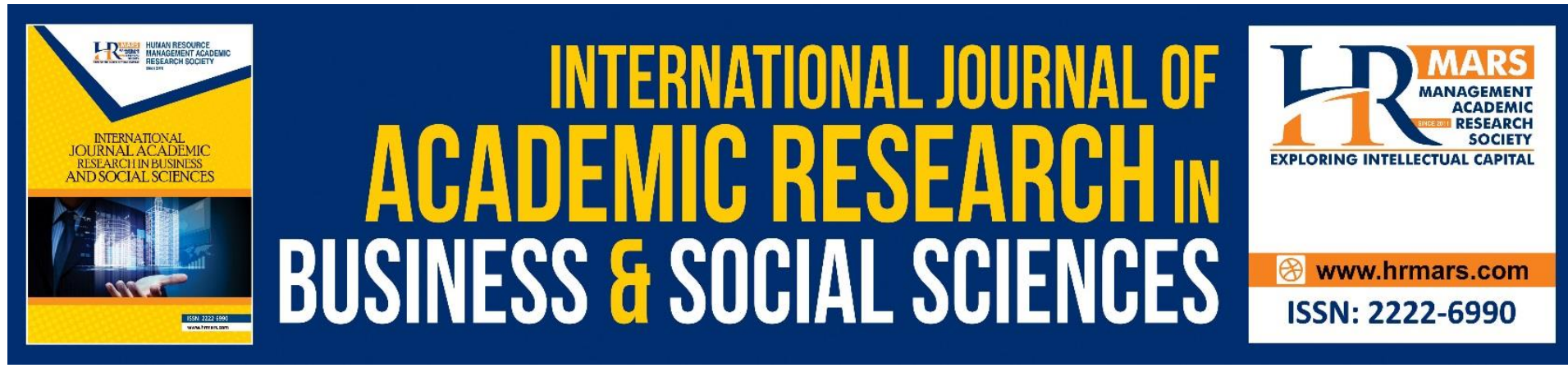

\title{
Servant Leadership Attributes and Employee Performance among Support Staff in A Malaysian Private University
}

\author{
Tak Jie Chan, Nur Amalia Rahwani Abd Rahim \\ Faculty of Business, Accountancy, Communication and Hospitality Management, SEGi \\ University, 47810, Petaling Jaya, Selangor, Malaysia \\ Email: chantakjie@segi.edu.my,maliabdrhm@gmail.com
}

\begin{abstract}
Saodah Wok
Department of Communication, Kulliyyah of Islamic Revealed Knowledge and Human Sciences, International Islamic University Malaysia, 53100, Gombak, Selangor, Malaysia

Email:wsaodah@iium.edu.my
\end{abstract}

\begin{abstract}
This study aims to examine the influence of servant leadership dimensions (Empowerment, Trust, Healing, Integrity, Service, and Communication) and employee performance among the support staff in one of the Malaysian private universities. The study utilised Leader-Member Exchange (LMX) and Social Exchange Theories to guide the study. Purposive sampling was employed in this study, where a quantitative (survey) method was used, in which questionnaires were distributed with only 51 valid responses received. The data were then analysed using Partial Least Squares Structural Equation Modelling through Smart-PLS 3.0. The results revealed that two (2) dimensions of servant leadership attributes (Communication and Empowerment) have a positive and significant relationship with employee performance; however, Healing found to have a negative but significant relationship with employee performance. In addition, Integrity, Service and Trust were found not significant to employee performance. Conclusion, implications, and suggestions for future study were also discussed. Keywords: Servant leadership, Employee Performance, Higher Education Institution, PLSSEM, Predictive Approach
\end{abstract}

\section{Introduction}

In the era of globalisation, leadership studies have gauged the attention of research in the contemporary working environment (Al Khajeh, 2018; Asghar \& Oino, 2018; Basit, Sebastian, \& Hassan 2017; Eva, Robin, Sendjaya, van Dierendonckd, \& Liden, 2019). Eva, Sendjaya, Prajogo, Cavanagh, and Robin (2018) argued that effective leadership is one of the main factors that contribute to the enhancement of employee's performance; thus, resulting in an increase of the overall organisational performance. In the education industry, there are various factors contributing to the effect of the employee performance and one of them is 
the leadership (Basit, et al., 2017; Khan \& Nawaz, 2016; Nawoselng'ollan \& Roussel, 2017). Sydney (2019) found that almost half of the employees interviewed said they have quit a job previously due to their bad managers. Furthermore, Bennett (2018) also stressed that $59 \%$ of the employees felt their managers do not prioritise the wellbeing of the employees, which caused employee attrition.

In an education context, leaders face enormous challenges; considering that leaders face constraints on budget, reducing wages, and termination of services (Barnes, 2015; Latif \& Marimon, 2019). In addition, Afzal, Din, and Qureshi (2018) indicated that the stress level of private universities staff was high compared to the public universities staff, due to the nature of private higher education institution as the servicing industry where the students (customers) are much more demanding and they have a high expectation of the university (Manzuma-Ndaaba, Harada, Nordin, Abdullateef, \& Romle, 2018). Based on the above notion, thus, it is indicated that higher education sector is facing an uncomplimentary situation for the employees, especially in the private education setting. In addition, some studies tend to ignore the most important role of educator that contributes towards having a better quality of the education industry, as well as for neglecting the supporting staff that supports the performance of the organisations to ensure that the operation runs smoothly, where it is still underrepresented in academic research (Che Nawi, Ismail, Ibrahim, Zamzamin, \& Jaini, 2016). In addition, previous studied samples were focused on the academic staff (Anjum \& Ghose, 2019; Latif \& Marimon, 2019) where the examination of the support staff was lacking, which justify to study support staff in the current setting, as the support staff members are the frontliners which have direct contact with the students as the customers.

However, past studies in the area of servant leadership mainly focus on the employees of organisations from the business sector (Muhtasom, Mus, Bijang, \& Latief, 2017; Nur Insan, 2020). In addition, there are research have also been done in the public sectors (Bayram \& Zoubi, 2020; Tuan, 2017), banking (Karatepe, Ozturk, \& Kim, 2019; Riquelme, Rios, \& Gadallah, 2020), airline (Alafeshat \& Aboud, 2019), but the influence of servant leadership attributes on the performance of the employees from the non-government organization (NGO) for example, higher education institution remains largely undiscovered (Brohi et al., 2018; Dube, Zikhali, \& Dube, 2019; Khuwaja, Ahmed, Abid, \& Adeel, 2020; Latif \& Marimon, 2019). As servant leadership changes the focus of leadership by promoting a leader-follower relationship, therefore, it has becomes increasingly crucial in the higher education sector (Wahyu, Tentama, \& Sari, 2019; Wilkins, Butt, \& Annabi, 2017). This has supported the notion of Wheeler (2012), that servant leadership is more applicable than any other type of leadership in the private education industry.

A majority of the past research that studied servant leadership and employee performance are based in China, Pakistan, Jordan, Indonesia, Middle East, USA, and Europe (Alafeshat \& Aboud, 2019; Alafeshat \& Tanova, 2019; Faraz, Mughal, Ahmed, Raza, \& lqbal, 2019; Su, Lyu, Chen, \& Zhang, 2020). Despite numerous studies have been done, research on understanding servant leadership on employee performance need further investigation especially in developing countries, particularly in the Malaysian setting (Rashid, Tasmin, Qureshi, \& Shafiq, 2017).

A variety of models have been found in the literature for the servant leadership. Although the characteristics of the models are distinctly different, these attributes remain intact, namely, empathy, conceptualisation, listening, persuasion, foresight, awareness, stewardship, healing, commitment to the followers' growth, and building community (Spears, 2004). Six main attributes have been established by Van Dierendonck (2011), namely, 
empowerment, humility, authenticity, interpersonal acceptance, direction, and management. Furthermore, the concept of servant leadership was also tested by Sun and Wang (2009), which included altruistic calling, emotional healing, persuasive mapping, wisdom, and community stewardship.

Overall, research on servant leadership has been relatively scarce in the higher education sector (Latif \& Marimon, 2019; Wilkins et al., 2017) due to the lack of empirical investigation (Bavik, Bavik \& Tang, 2017), where the specific dimensions of servant leadership: (1) Empowerment, (2) Trust, (3) Healing, (4) Integrity, (5) Communication, and (6) Service require further investigation, especially in the context of private higher education institutions in Malaysia, where this have supported the notion of Aboramadan, Dahleez, and Hamid (2020) who urged to test servant leadership and employees' outcomes in different cultures to gain more insight, which justify to carry out servant leadership's research in Malaysian education setting.

Based on the above voids highlighted, the current study aims to investigate the relationships between the attributes of servant leadership (Empowerment, Trust, Healing, Integrity, Communication, and Service) and employee performance in a private university.

\section{Literature Review}

\section{Theoretical Foundations}

The Leader-Member Exchange (LMX) theory is an interpersonal theory of leadership which is based on the relationships, initially developed by Dansereau, Cashman, and Graen (1973). The interchange of high quality is characterised by mutual confidence, liking and respect and thus, it has consequences for employee well-being and performance in relation to the essence of the quality of relationships (Erdogan \& Bauer, 2015). When managers provide greater organisational support (Erdogan \& Enders, 2007), the attitudes and performance of employees are influenced more effectively by the effects of LMX quality.

In addition, social exchange theory (SET) was also adopted in this study to explain the relationship between servant leadership and employees performance. The theory is a concept based on the notion that a reciprocal relationship between two parties is established through an analysis of cost and benefit (Gergen, 1969). Homans (1961) contended that when individuals receive more benefits than the risks, they are more likely to retain the relationship, and in return when individuals outweigh the risks over benefits, they will abandon the relationship. Hence, by applying SET in this research, employees who have benefited from the leaders and his/her style will perceive the institution in a positive light; thus, contributing positively to the organisational performance. In contrary, when company leaders fail to meet the benefits and expectations of employees, negative perception will be formed; affecting the performance of the employees. When employees benefitted positively from the leaders, they tend to exchange the feel good factor and satisfaction obtained into higher performance which in the long-run, will lead to improved productivity (Muller, Smith, \& Lillah, 2018).

\section{Definition of Servant Leadership}

Servant Leadership was first presented by Greenleaf in 1970, where it was basically defined as the most successful leaders are to be the people's servants (Greenleaf, 1998). In addition, Ye, Lyu, and He (2019) defined servant leadership as a style of leadership in which leaders prioritise honesty and dedicate themselves to the advancement of others. Leaders aim to place their employees' needs first, assist supporters to understand their full potential and inspire supporters to accomplish their job (Liden, Wayne, Liao, \& Meuser, 2014). Although 
leaders are primarily employee managers, they also support by displaying their unconditional responsibility for the societies and at the same time, encouraging others to work together towards a common goal (Searle \& Barbuto, 2010). The complementary successful operation of servant leadership will help to achieve the employee performance.

\section{Employee Performance}

The performance of an employee refers to the job and activities performed efficiently. The employee's individual success is a positive contribution to the organisation's performance (Mensah, 2015; Saleem \& Amin, 2013). In addition, Mensah (2015) defined employee performance as an employee's positive contribution to the organisation's success. High work performance improves the productive potential of workers, helps them to meet specific objectives and increases their morale and job satisfaction (Davidescu, Apostu, Paul \& Casuneanu, 2020). However, it depends on the interaction between different individual features such as personalities and situational factors to manage a job effectively and to achieve a high job performance (Alsuwailem \& Elnaga, 2016). Hence, a careful choice of employees for a particular job will therefore lead to achieve their required work performance.

\section{Relationship between Servant Leadership and Employee Performance}

Nur Insan (2020) highlighted that superiors would have an important role in affecting their employees' performance in an organisation. This has aligned with the research findings of Oter-Neira, Varela-Neira, and Bande (2016), and Muhtasom et al., (2017). In addition, servant leadership was also found to have a positive significant impact on various performances such as (financial, customer, internal process, learning, and innovation) based on the balanced scorecard (Muller et al., 2018).

Ye et al., (2019) aimed to investigate the servant leadership and proactive customer service performance (PCSP) which mediated sequentially by harmonious passion and customer's orientation, and the moderating role of contingent self-esteem in China hotels. The results revealed that servant leadership can help boost the PCSP of the hotel employees. This has aligned with the study of Rahsid et al., (2017) where servant leadership has positive relationship with organizational citizenship behaviour (OCB) which further explains the approach of servant leadership to maintain the integrity and to build a long lasting relationship with the employees.

In addition, in the Spanish higher education context, Latif and Marimon (2019) investigated servant leadership which influenced the life satisfaction of academic staff through the career satisfaction as a mediator. The findings revealed that the servant leadership was made up of multi-faceted dimensions, namely, behave ethically, development, pioneering, wisdom, emotional healing, empowerment, and relationship building. In addition, there is a competitive mediation between servant leadership and life satisfaction.

Sihombing, Astuti, Al-Musadieq, Hamied, and Rahardjo (2018) investigated the influence of servant leadership on employee's performance, through the mediation of rewards and organisational culture in Indonesian banking institution. The results showed that servant leadership influenced rewards and organisational culture, but surprisingly, it did not have significant impact with employee's performance. This is similar to the results of Lor and Hassan (2017) who found that servant leadership style did not affect the employee's performance in jewellery industry in Malaysia. 
In addition, Simamora, Sudiarditha, and Yohana (2019) had examined the influence of servant leadership on employees' performance through the engagement and OCB as the mediating variables in Mandiri Inheallth, Indonesia. The results revealed that servant leadership can improved the employees' performance positively; however, engagement and OCB does not mediated the relationship between servant leadership and OCB. This is also congruent with the study of Hernández-Perlines and Araya-Castillo (2020) which showed servant leadership contributed positively to the performance of the third sector, and innovation has a full mediation between these relationships.

In private airline industry, Alafeshat and Aboud (2019) investigated the impact of servant leadership on organisational performance (employee satisfaction and retention) via the employee engagement as the mediator. The results indicated that servant leadership was positively affecting the employee performance (satisfaction and retention), and employee engagement was found to partially mediate the relationship between servant leadership and employee satisfaction and retention as an indicator of organisational performance.

Based on the above discussion, leaders empower their followers by training and guidance, as well as by providing sufficient resources and authority that are crucial for the progression of the company. According to Chiniara and Bentein (2016), the important attribute that significantly affects performance is the empowerment of the leaders. Furthermore, Khan, Khan, and Zeeshan (2016) concluded that empowerment has a positive and significant effect on employee performance (motivation). The positive and significant variation of employee performance due to empowerment can be explained that employees would be more willing to achieve higher levels of performance with sufficient authority, power, autonomy, and independence to make decision on their jobs. Moreover, Choudhary, Akhtar, and Zaheer (2013) found that servant leaders would empower their followers to enhance the communication and performance.

Additionally, trust is built as leaders display honesty, authenticity, and quality in their actions (Kouzes \& Posner, 2003; Yukl, Gordon, \& Taber, 2002). LMX theory relies strongly on the assumption that leaders influence the value of their connections with employees in their group. According to the study by Hussain and Ali (2012), trust has shown a positive impact on the employee performance; as such trustworthy relationship between leaders and followers encourages a culture that always allows employees to increase their level of performance. This has further supported the notion that trust can help portray servant leadership and transform it into the positive individual performance (Saleem, Zhang, Gopinanth \& Adeel, 2020).

Barbuto and Wheeler (2006) highlighted that emotional healing is part of the commitment and skill of a leader to promote spiritual healing from any hardships or trauma an individual has faced. Emotional healing leaders are extremely caring and excellent listeners. They build environments which ensure that personal and professional issues are addressed by their employees. Muhtasom, et al. (2017) found that healing has a direct and significant impact on employee performance, whereby it is portrayed that the managers in their study have shown a conducive environment for their employees.

Parolini (2004) concludes that integrity is summed up as a devotion of the leader to an objective range of moral principles, which contributes to inner and outer honesty, confidence, and fairness that is beneficial for the good of the employees. Particularly, integrity is considered a crucial aspect of the operation of private organisations (Sani, Endin, Masrek, Sahid, Baba, \& Kamis, 2016). A study carried out by Awaludin, Adam, and Mahrani (2016) has shown that integrity was found to have significant and positive impact on employee 
performance. According to Zarim and Zaki (2016), integrity implemented within the company reveals a positive response to the employee perception. With the perception of the employees being positive, it would thus create a high level of performance.

Good communication is a pivotal tool to achieve high performance and to establish positive working relationships within the company. Trust among employees can be established if everyone communicates effectively (Hee, Qin, Kowang, Husin, \& Ping, 2019). Efficient communication increases the performance of the employees and therefore binds the employees together. Hee et al. (2019) and Ezerman with Sintaasih (2018) found that communication has an overall positive and significant relationship with employee performance, including OCB. Communication encourages the employees to work together and thus reflects an improvement of the performance. This has aligned with the study of Neves and Eisenberger (2012) who also found that an effective method of increasing employee performance would be an open communication, primarily due to the company showing interest in the wellbeing of the employees and values the contributions of their employees.

According to the study by Albloshi and Nawar (2015), one of the aspects of the Servant Leadership was service to other people. Muhtasom et al., (2017) found that through the service applied by the managers, employees were able to run their activities well which in return improved their performance. Furthermore, service has been shown to affect other variables such as the intent to stay among the employees in an organisation (Hajjaj, 2014). When the employees feel the sense of belonging in the organisation, it would lead to an increase in performance.

Based on the discussion above, therefore, the current study hypothesised that:

$\mathrm{H}_{1}$ : There is a positive relationship between communication and employee performance.

$\mathrm{H}_{2}$ : There is a positive relationship between empowerment and employee performance.

$\mathrm{H}_{3}$ : There is a positive relationship between healing and employee performance.

$\mathrm{H}_{4}$ : There is a positive relationship between integrity and employee performance.

$\mathrm{H}_{5}$ : There is a positive relationship between service and employee performance.

$\mathrm{H}_{6}$ : There is a positive relationship between trust and employee performance.

\section{Methods}

\section{Research Design}

This study used a quantitative research design in order to collect reliable and accurate data. Quantitative design is used as it involves the reduction of phenomena to numerical values (Apuke, 2017). The survey method by using questionnaire was utilised as it is a very efficient method as it allows for the standardising of the collection of quantitative data, so that the data is internally consistent and comprehensible to analyse (Roopa \& Rani, 2012).

\section{Sampling Procedure}

The study was performed using a purposive sampling technique to solicit the responses from the support staff in a private university. Purposive sampling is a sampling technique that focuses on subjects who possess a particular characteristic which could be a more ideal in the research (Etikan, Musa \& Alkassim, 2016). A non-probability sampling was used in this study as researchers were unable to get the sampling frame (population's list). In addition, in order to know the sample size for the current study, researchers used A-priori sample size technique (Sooper, 2020 in Memon et al., 2020) via the power analysis as it is a prominent analysis in most business and social sciences research as suggested by Hair, Hult, Ringle, and Sarstedt 
(2017), and the sample size via the G*Power 3.1.9.2 software indicated that the sample size for the current study is 98 (effect size: 0.15; power: 80; number of predictors: 6). However, researchers only managed to get 51 valid responses due to the difficult times when movement control order (MCO) being implemented for the COVID-19. Hence, the response rate was $52 \%$. Although the sample size was not really sufficient, however, Babbie (2015) and Goves (2006) argued that response rate of at least $50 \%$ is considered adequate for analysis and reporting. This has further been supported by Sekaran and Bougie (2016) who recommended that sample size between 30 and 500 are still sufficient for the social science studies.

\section{Measurement}

The questionnaire contains 3 sections. Section $A$ is a demographic section, which was designed to collect demographic information of the respondents, namely, gender, age, race, education level achieved, years of employment in the institution, and the department the staff works in.

Section B pertains to the dimensions of Servant Leadership, namely, Empowerment, Trust, Healing, Integrity, Communication, and Service which were adapted from numerous scholars (Barbuto \& Wheeler, 2006; Dennis \& Bocarnea, 2005; Latiff, Majid, \& Mohamad, 2017; Liden Wayne, Zhao, \& Henderson, 2008; Spector, 1985; Wong \& Page, 2000). Section C consists of Employee Performance wherein the items used were adapted from Tjosvold, $\mathrm{Yu}$, and Hui (2004) and Kazan and Gumus (2013). The survey items for Section B and Section C were designed as statements, measured on the five-point Likert type scale, i.e., 1 = Strongly Disagree, 2 = Disagree, 3 = Somewhat Agree, 4 = Agree, and 5 = Strongly Agree.

\section{Statistical Analysis and Significance}

All the hypotheses developed were tested using Structural Equation Modelling (SEM). Twostage analytical procedures were performed using Smart-PLS 3.0. SEM is deemed a suitable statistical tool for this study as PLS-SEM can handle complex models where there are many numbers of latent variables and constructs (Henseler, Ringle, \& Sinkovics, 2009). In addition, PLS-SEM can also handle the data from non-probability sampling, with a small sample size and from non-normal distribution data (Awang, Afthanorhan, \& Asri, 2015; Hair, Risher, Sarstedt, \& Ringle, 2019). Most significantly, the current study implied to test the theoretical framework based on the perspective of prediction which justifies the use of PLS-SEM (CepedaCarrion, Cegarra-Navarro, \& Cillo, 2019; Hair et al., 2019). This has further supported the notion of Rigdon (2016), that the prediction analysis is timely in research as it provides new observations within and outside of the sample.

\section{Results}

Based on Table 1, majority of the respondents are female (70.6\%), with only $29.4 \%$ of the respondents being male. In terms of age, $41.2 \%$ of the respondents aged from 30-34 years old, followed by those from 35 years old and above (45.0\%), and the rest (13.8\%) were aged between 20-29 years old. Additionally, more than half of the respondents are Malays (64.7\%), followed by Chinese (21.6\%), Indians (9.8\%), and the others made up the rest of the respondents (3.9\%). More than half of the respondents have Bachelor's Degree (52.9\%), Master's Degree (15.7\%) and another 31.4\% of them having Professional Certificate/Diploma; which reveals that the respondents are educated. Furthermore, 39.2\% of the respondents have been employed in the university ranging from 5-9 years, while $24.5 \%$ of them have been 
working for more than 10 years, with only $35.3 \%$ of them have their working experience of 14 years; thus, indicating that they have worked in the university for a long period of time and they understand the leadership styles practised by their superiors at the various departments: Marketing (35.3\%), Library (25.5\%), Student Affairs (21.6\%), Registry (11.8\%), and Bursary (5.8\%).

Table 1: Demographic profile of the respondents $(n=51)$

\begin{tabular}{|c|c|c|}
\hline Variable(s) & Frequency & $\%$ \\
\hline \multicolumn{3}{|l|}{ Gender } \\
\hline Male & 15 & 29.4 \\
\hline Female & 36 & 70.6 \\
\hline \multicolumn{3}{|l|}{ Age } \\
\hline $20-24$ & 1 & 2.0 \\
\hline $25-29$ & 6 & 11.8 \\
\hline $30-34$ & 21 & 41.2 \\
\hline $35-39$ & 6 & 11.8 \\
\hline $40-44$ & 11 & 21.4 \\
\hline $45-59$ & 6 & 11.8 \\
\hline \multicolumn{3}{|l|}{ Race } \\
\hline Malay & 33 & 64.7 \\
\hline Chinese & 11 & 21.6 \\
\hline Indian & 5 & 9.8 \\
\hline Others & 2 & 3.9 \\
\hline \multicolumn{3}{|l|}{ Education } \\
\hline Bachelor Degree & 27 & 52.9 \\
\hline Master Degree & 8 & 15.7 \\
\hline $\begin{array}{l}\text { Professional Certificate / } \\
\text { Diploma }\end{array}$ & 16 & 31.4 \\
\hline \multicolumn{3}{|l|}{ Years of Employment } \\
\hline$<=1-4$ years & 18 & 35.3 \\
\hline $5-9$ years & 20 & 39.2 \\
\hline $10-14$ years & 11 & 21.6 \\
\hline 15 years or more & 2 & 3.9 \\
\hline \multicolumn{3}{|l|}{ Department } \\
\hline Marketing & 18 & 35.3 \\
\hline Library & 13 & 25.5 \\
\hline Student Affairs & 11 & 21.6 \\
\hline Registry & 6 & 11.8 \\
\hline Bursary & 3 & 5.8 \\
\hline
\end{tabular}

Before testing the model, this study examined the common method variance (CMV) which is the method bias or same source bias that may arise using self-report measures from the similar sample in the survey method (Podsakoff, MacKenzie, Lee, \& Podsakoff, 2003). In this 
study, correlation matrix procedure was used as one of the methods to detect CMV (Bagozzi, Yi, \& Phillips, 1991; Tehseen, Ramayah, \& Sajilan, 2017). CMV occurs when there is a substantially high correlation is found among latent variables $(r>0.9)$. The outcome of the correlation test indicated that none of the latent variables correlated more than 0.90 . Hence, the results assured that CMV was not an issue in this study.

Table 2: Correlations matrix among the variables

\begin{tabular}{|c|c|c|c|c|c|c|c|}
\hline & 1 & 2 & 3 & 4 & 5 & 6 & 7 \\
\hline 1.Communication & 1 & & & & & & \\
\hline 2. Empowerment & $.544^{* *}$ & 1 & & & & & \\
\hline 3. Healing & $.391^{* *}$ & $.316^{*}$ & 1 & & & & \\
\hline 4. Integrity & $.548^{* *}$ & $.680^{* *}$ & $.491^{* *}$ & 1 & & & \\
\hline 5. Service & $.548^{* *}$ & $.587^{* *}$ & $.631^{* *}$ & $.826^{* *}$ & 1 & & \\
\hline 6. Trust & $.479^{* *}$ & $.651^{* *}$ & $.381^{* *}$ & $.774^{* *}$ & $.712^{* *}$ & 1 & \\
\hline 7. Performance & $.726^{* *}$ & $.553^{* *}$ & .132 & $.310^{*}$ & $.381^{* *}$ & $.432^{* *}$ & 1 \\
\hline
\end{tabular}

${ }^{* *}$ Correlation is significant at the 0.01 level (1-tailed).

${ }^{*}$ Correlation is significant at the 0.05 level (1-tailed).

\section{Measurement Model}

For the measurement model, convergent validity and discriminant validity were assessed. The convergent validity of the measurement model was ascertained through factor loadings, average variance extracted (AVE), and composite reliability (CR) (Hair et al., 2017).

As presented in Table 3, the factor loadings were all greater than 0.6 which complied with as suggested by Bryne (2016). Item I3 was deleted as the item loading found to be less than 0.6. In addition, the CR and AVE obtained were also higher than 0.7 and 0.5 , respectively (Hair et al., 2017). Hence, all the convergent validity criteria were met.

Discriminant validity is established if all the HTMT values obtained are less than the required threshold of HTMT.90 as per suggested by Gold, Malhorta and Segars (2001). As shown in Table 4, all the HTMT values less than HTMT.90 indicating that discriminant validity is ascertained. Collinearity issue was assessed using variance inflation factor (VIF) with a cut-off value of 5 as suggested by Hair et al. (2017). The VIF values as presented in Table 5 were all less than 5 indicating no collinearity issues. 
INTERNATIONAL JOURNAL OF ACADEMIC RESEARCH IN BUSINESS AND SOCIAL SCIENCES Vol. 11, No. 2, 2021, E-ISSN: 2222-6990 @ 2021 HRMARS

Table 3: Convergent Validity

\begin{tabular}{|c|c|c|c|c|c|}
\hline \multirow[b]{2}{*}{ Construct } & \multicolumn{5}{|c|}{ Cronbach's } \\
\hline & Items & Loadings & Alpha & CR & AVE \\
\hline \multirow[t]{4}{*}{ Communication } & Com1 & 0.847 & 0.879 & 0.917 & 0.736 \\
\hline & Com2 & 0.930 & & & \\
\hline & Com3 & 0.825 & & & \\
\hline & Com4 & 0.824 & & & \\
\hline \multirow[t]{4}{*}{ Empowerment } & E1 & 0.846 & 0.884 & 0.920 & 0.741 \\
\hline & E2 & 0.883 & & & \\
\hline & E3 & 0.883 & & & \\
\hline & E4 & 0.830 & & & \\
\hline \multirow[t]{4}{*}{ Healing } & $\mathrm{H} 1$ & 0.914 & 0.943 & 0.953 & 0.835 \\
\hline & $\mathrm{H} 2$ & 0.893 & & & \\
\hline & $\mathrm{H} 3$ & 0.929 & & & \\
\hline & $\mathrm{H} 4$ & 0.919 & & & \\
\hline \multirow[t]{3}{*}{ Integrity } & $\mid 1$ & 0.922 & 0.809 & 0.877 & 0.710 \\
\hline & 12 & 0.930 & & & \\
\hline & 14 & 0.643 & & & \\
\hline \multirow[t]{7}{*}{ Service } & S1 & 0.820 & 0.931 & 0.943 & 0.705 \\
\hline & S2 & 0.779 & & & \\
\hline & S3 & 0.869 & & & \\
\hline & S4 & 0.891 & & & \\
\hline & S5 & 0.930 & & & \\
\hline & S6 & 0.808 & & & \\
\hline & S7 & 0.765 & & & \\
\hline \multirow[t]{4}{*}{ Trust } & $\mathrm{T} 1$ & 0.881 & 0.903 & 0.931 & 0.771 \\
\hline & $\mathrm{T} 2$ & 0.898 & & & \\
\hline & T3 & 0.811 & & & \\
\hline & T4 & 0.920 & & & \\
\hline Employee & & & 0.888 & & \\
\hline \multirow[t]{8}{*}{ Performance } & EP1 & 0.697 & & 0.911 & 0.562 \\
\hline & EP2 & 0.686 & & & \\
\hline & EP3 & 0.792 & & & \\
\hline & EP4 & 0.719 & & & \\
\hline & EP5 & 0.787 & & & \\
\hline & EP6 & 0.760 & & & \\
\hline & EP7 & 0.792 & & & \\
\hline & EP8 & 0.758 & & & \\
\hline
\end{tabular}

$\mathrm{CR}=$ Composite reliability; AVE = Average Variance Extracted 
Table 4: Discriminant Validity Using HTMT Ratio

\begin{tabular}{lccccccc}
\hline & 1 & 2 & 3 & 4 & 5 & 6 & 7 \\
\hline 1 Communication & & & & & & & \\
2 Empowerment & 0.623 & & & & & & \\
3 Healing & 0.431 & 0.345 & & & & \\
4 Integrity & 0.653 & 0.885 & 0.411 & & & \\
5 Service & 0.613 & 0.661 & 0.671 & 0.882 & & \\
6 Trust & 0.543 & 0.728 & 0.414 & 0.895 & 0.781 & \\
7 Performance & 0.818 & 0.619 & 0.205 & 0.478 & 0.423 & 0.479 \\
\hline
\end{tabular}

\section{Structural Model}

The structural model was tested using bootstrapping procedures with a resample of 5,000 (Hair et al., 2017) to assess all the relationship between the constructs, its corresponding beta and $t$-values. The results are shown in Table 5.

Communication $\left(\theta=0.714, t=6.403, f^{2}=0.805\right)$, and empowerment $\left(\theta=0.350, t=1.981, f^{2}\right.$ $=0.130$ ) were found to have a positive relationship with employee performance, but healing ( $b=-0.205, t=1.766, f^{2}=0.097$ ) was found to have a negative relationship with employee performance. However, Integrity, Service, and Trust showed no significant relationship with employee performance. This gives support for $\mathrm{H}_{1}, \mathrm{H}_{2}$, and $\mathrm{H}_{3}$ was partially supported as it has negative relationship, whereas $\mathrm{H}_{4}, \mathrm{H}_{5}$, and $\mathrm{H}_{6}$ were rejected. $R^{2}$ of 0.635 suggests that there is $63.5 \%$ of the variation in employee performance was explained by the six attributes of servant leadership. In this study the $Q^{2}$ values are more than zero for employee performance $\left(Q^{2}=0.317\right)$, suggesting that the model has sufficient predictive relevance.

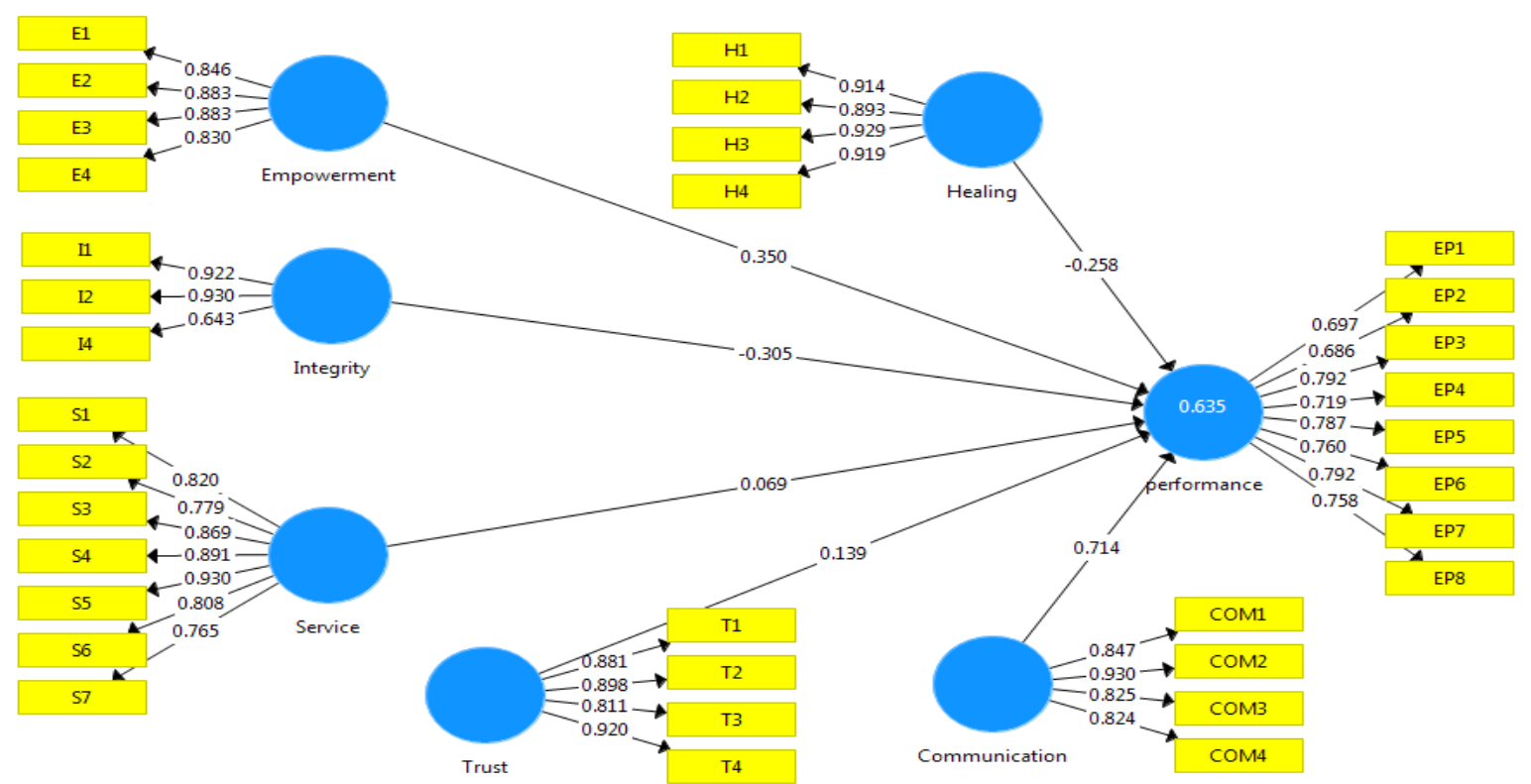

Figure 1: Structural model 
Table 5: Direct Effects

Std.

\begin{tabular}{|c|c|c|c|c|c|c|c|c|c|}
\hline $\begin{array}{l}\text { Hypothes } \\
\text { is }\end{array}$ & Relationship & $\begin{array}{l}\text { Std. } \\
\text { Beta }\end{array}$ & $\begin{array}{c}\text { Erro } \\
r\end{array}$ & $\begin{array}{c}\text { t- } \\
\text { value }\end{array}$ & Decision & $\mathbf{R}^{2}$ & $\mathbf{Q}^{2}$ & $f^{2}$ & VIF \\
\hline & Communicatio & & & & & & & & \\
\hline & $\mathrm{n}->$ & 0.71 & 0.11 & 6.403 & Support & 0.63 & 0.31 & 0.80 & 1.73 \\
\hline \multirow[t]{2}{*}{$\mathrm{H} 1$} & Performance & 4 & 2 & ** & ed & 5 & 7 & 5 & 5 \\
\hline & Empowerment & 0.35 & 0.17 & 1.981 & Support & & & 0.13 & 2.58 \\
\hline \multirow[t]{3}{*}{$\mathrm{H} 2$} & ->Performance & 0 & 7 & ${ }^{*}$ & ed & & & 0 & 7 \\
\hline & & - & & & Partially & & & & \\
\hline & Healing -> & 0.25 & 0.14 & 1.766 & Support & & & 0.09 & 1.88 \\
\hline \multirow[t]{3}{*}{ H3 } & Performance & 8 & 6 & ${ }^{*}$ & ed & & & 7 & 7 \\
\hline & & - & & & Not & & & & \\
\hline & Integrity -> & 0.30 & 0.24 & & Support & & & 0.06 & 3.76 \\
\hline \multirow[t]{2}{*}{$\mathrm{H} 4$} & Performance & 5 & 7 & 1.233 & $\begin{array}{c}\text { ed } \\
\text { Not }\end{array}$ & & & 8 & 0 \\
\hline & Service -> & 0.06 & 0.19 & & Support & & & 0.00 & 4.17 \\
\hline \multirow[t]{2}{*}{ H5 } & Performance & 9 & 4 & 0.335 & ed & & & 3 & 1 \\
\hline & Trust -> & 0.13 & 0.19 & & Support & & & 0.01 & 2.71 \\
\hline $\mathrm{H} 6$ & Performance & 9 & 9 & 0.698 & ed & & & 9 & 7 \\
\hline
\end{tabular}

PLSpredict was used to examine the predictive power of the model under study. Based on Table 6, the results of the PLS-SEM model is compared to the results of the naive linear regression (LM) benchmark model. As all $Q^{2}$ predict values are more than zero, hence, it can proceed with the comparison of both models. The comparison of predictive power (PLS-SEM - LM) is carried out using the root mean squared error (RMSE), which has high symmetrically distributed prediction errors (Shmueli et al., 2019). When the RMSE statistical values of the PLS-SEM model is compared to naïve LM benchmark model, the majority of the indicators show that RMSE values of PLS-SEM are lesser than the RMSE values of the naïve LM benchmark. Therefore, it suggests that the model has a high predictive power for employee performance.

Table 6: PLSpredict Assessment of Variables

\begin{tabular}{|c|c|c|c|c|}
\hline \multirow[b]{2}{*}{ Items } & \multicolumn{2}{|c|}{ PLS-SEM } & \multirow{2}{*}{$\begin{array}{c}\text { LM } \\
\text { RMSE }\end{array}$} & \multirow{2}{*}{$\begin{array}{c}\text { PLS-SEM - LM } \\
\text { RMSE }\end{array}$} \\
\hline & RMSE & $Q^{2}$ _predict & & \\
\hline EP4 & 0.559 & 0.292 & 1.057 & -0.498 \\
\hline EP5 & 0.572 & 0.180 & 1.137 & -0.565 \\
\hline EP8 & 0.607 & 0.375 & 1.112 & -0.505 \\
\hline EP3 & 0.583 & 0.308 & 1.080 & -0.497 \\
\hline EP7 & 0.551 & 0.232 & 0.943 & -0.392 \\
\hline EP2 & 0.651 & 0.255 & 0.965 & -0.314 \\
\hline EP6 & 0.570 & 0.256 & 1.184 & -0.614 \\
\hline EP1 & 0.791 & 0.041 & 1.103 & -0.312 \\
\hline
\end{tabular}

\section{Discussion}

The results of this study supported numerous past studies that servant leadership style has a positive effect on the performance of employees (Alafeshat \& Aboud, 2019; Hashim, Khan, \& 
Adnan, 2019; Muhtasom et al., 2017, Eva, et al., 2018). Furthermore, it could be reported that the Communication attribute of Servant Leadership is the main determinant that contributes towards the performance of the employees.

Communication shows to be a strong predictor with employee performance. Muchlas (2014) has clarified that communication would encourage the employees to perform better. In addition, communication strengthens the relationship between the managers and employees as it creates a mutual understanding between the managers and employees that assist in creating meaningful relationships between the managers and the employees, thus, impacting the performance of the employees (Ezerman \& Sintaasih, 2018). Leaders would develop an efficient, competent, and powerful leadership style by communicating their values and ensuring that all their subordinates know the organisational strategy and embrace effective communication (De Waal \& Sivro, 2012). When the servant leaders understand the thought processes of the employees, it would be imperative for them as they make a collaborative effort to create such environment that encourages open communication, thus motivating the employees to enhance their performance (Thompson \& Webber, 2016).

Empowerment was found to have a significant relationship with employee performance (Khan et al., 2016). The significant positive relationship in employee performance due to empowerment can further be explained by the respondents who are employed in the university studied since they have been working for more than 5 years, which indicates that they have been working in the university studied for a long period of time. Hence, the leader will empower the subordinates by giving them authority to handle their daily tasks.

On the other hand, Healing have a significant impact on the performance of employees, but it has a negative relationship which contradicted to the study of Muhtasom et al. (2017). A possible reason that healing has the negative impact on employee performance would be due to the cultural practices of the institution, as the culture of the organisation may not be open but bureaucratic, and therefore, employees would perform better if the managers and supervisors themselves would express their feelings openly (Gharibvand, 2012). Servant leaders are supposed to have a particular emphasis on the emotional healing of their followers as it eases their mental health; helps them to grow professionally and individually which in turn motivates them to improve their performance (Wheeler, 2012).

Hence, based on the discussions above, it can be summarised that Communication and Empowerment affect the employee performance positively, but Healing has a negative impact on employee performance. However, each private university would vary on the dimensions depending on which attributes of Servant Leadership that the institutions focus on.

\section{Conclusion}

This study attempted to examine the relationship between the dimensions of Servant Leadership and Employee Performance in a Malaysian private university. The findings revealed that dimensions of Servant Leadership, namely, Communication and Empowerment influence Employee Performance positively and Communication being the most prominent determinant that was perceived highly among the support staff in the private university concerned. 


\section{Academic Implications}

This study supports the determinants of Servant Leadership by investigating and contextualising a framework by focusing on the multidimensional facets of Servant Leadership. When the superiors provide greater organisational support to the employees, the attitudes and performance of the employees would be influenced more effectively by the effects of the LMX relationship quality (Erdogan \& Enders, 2007). Specifically, this study provides an avenue for researchers to explore further on any of the dimensions that is scarce and less explored in their future research.

The reciprocal relationship is evident in the findings, suggesting that the delivery of Servant Leadership attributes as the input in the SET, where these inputs will help to drive positive improvement in employees' perceptions about the university and in return will lead to positive performance.

\section{Practical Implications}

The findings of this study give insights for the management of the private university to implement Servant Leadership among superiors and to chart the implementing this leadership style will impact their employee performance. Therefore, the management of the institution should encourage a system of empowerment as it indicates sufficient authority and independence. For instance, the management of the university should give more freedom and authority to the support employees and trust them in performing their tasks. This will help to nurture the supportive culture and will make the support staff feel appreciated, satisfied and willing to go extra miles for the organisation (Chan, Wong, \& Wok, 2017).

Although Communication as part of the servant leadership attributes was perceived prominent by the support staff, especially an effective communication will help in establishing positive working relationships, through employing social support services to their followers. This would have a great advantage in the academic sector, where servant leadership would primarily nurture the human capital and development of the employees. Hence, the human resources of the university should also organise courses and trainings for the leaders to enhance their communication and persuasive skills, and how to communicate with their subordinates in a more appropriate way, instead of just giving instruction top-down, and asking the subordinates to follow.

In addition, Trust and Integrity were not well perceived by the support staff which resulted in the insignificant results. Thus, the top management of the university should have a whistle blower policy for the employees to channel up their grievances to the top management in term of the wrong doings of their superiors such as exploitation of the rights and favouritism. The initiatives formulated should protect the employees, where according to LMX theory, members who are trusted by the leader (in-role), will receive more works compared to the out-role members. Hence, this will result in the situation wherein the employees will feel that they are being punished for doing good jobs. Hence, it will lead to the low morale and motivation, and it will further lead to turnover which causes the organisation loosing potential human capital. Thus, top management should make sure that their superiors give equal treatment to their employees, to gauge the trust of the members, so that the employees can perform effectively to achieve the goals of the organisation. 


\section{Suggestions for Future Study}

This study has several limitations. First, the number of respondents was only 51 which are not able to generalise to the population of support staff in the university under studied. Hence, future study should increase the number of respondents to yield better results.

In addition, the current study focuses only on one private university. Hence, future studies can include more organisations in the same industry or other service industries, for instance, retailing and hospitality, to increase the varieties in the research perspectives and to increase its validity.

A crucial limitation is the social desirability bias, whereby the respondents would respond to what they perceive as socially desirable as the employees would fear of the negative consequences if the data would be exposed to the management of the institution. Regardless, the respondents have been assured by the researchers of their confidentiality and anonymity. This helps to minimise this limitation.

For future studies, researchers are recommended to pursue a mixed-method by combining quantitative and qualitative techniques to better understand how the variables are related to each other. Future studies may also analyse the influence of mediating variables, such as organisational culture, organisational commitment, and employer branding, to name a few and to test the moderating role of demographic variables on the current framework to add new insights to the literature of leadership and organisational studies.

\section{References}

Aboramadan, M., Dahleez, K., \& Hamid, M. H. (2020). Servant leadership and academics outcomes in higher education: The role of job satisfaction. International Journal of Organizational Analysis. Ahead-of-print. DOI: 10.1108/IJOA-11-2019-1923

Afzal, S., Din, M., \& Qureshi, I. A. (2018). Comparing the stress level of teachers at public and private universities in Pakistan. Journal of Education Research, 21(1), 106.

Al Khajeh, E. H. (2018). Impact of leadership styles on organisational performance. Journal of Human Resources Management Research, 1-10. DOI: 10.5171/2018.687849

Alafeshat, R., \& Aboud, F. (2019). Servant leadership impact on organisational performance: The mediating role of employee engagement. International Journal of Human Resource Studies, 9(3), 85-100. DOI:10.5296/ijhrs.v9i3.15047

Alafeshat, R., \& Tanova, C. (2019). Servant leadership style and high-performance work system practices: Pathway to a sustainable Jordanian airline industry. Sustainability, 11, 1-21. DOI: $10.3390 /$ su11226191

Albloshi, F. A., \& Nawar, Y. S. (2015). Assessing the impact of leadership styles on organisational performance: The case of Saudi private SME's. Journal of Organisational Studies and Innovation, 2(2), 66-77.

Alsuwailem, A., \& Elnaga, A. A. (2016). Exploring the relationship between personality and job performance: New approach. International Journal of Business and Management Invention, 5(12), 43-53.

Anjum, N., \& Ghose, U. (2019). Workplace stress: A critical insight of causes and effects on employees' wellbeing - A study on private university teaching staff. International Journal of Academic Research in Business, Arts and Science, 1(3), 124-138. DOI: 10.5281/zenodo.3510630

Apuke, O. D. (2017). Quantitative research methods: A synopsis approach. Arabian Journal of Business and Management Review (Kuwait Chapter), 6(10), 40-47. DOI: 10.12816/0040336 
Asghar, S., \& Oino, I. (2018). Leadership styles and job satisfaction. Market Forces, 13(1), 113.

Awaludin, I., Adam, L. O. B., \& Mahrani, S. W. (2016). The effect of job satisfaction, integrity, and motivation on performance. The International Journal of Engineering and Science, 5(1), 47-52.

Awang, Z., Afthanorhan, A., \& Asri, M. A. M. (2015). Parametric and non-parametric approach in Structural Equation Modeling (SEM): The application of bootstrapping. Modern Applied Science, 9(9), 58-67. DOI:10.5539/mas.v9n9p58

Babbie, E. R. (2015). The practice of social research (14 ${ }^{\text {th }} \mathrm{Ed}$.). Belmont, CA: Thomson Wadsworth.

Bagozzi, R. P., Yi, Y., \& Phillips, L. W. (1991). Assessing construct validity in organizational research. Administrative Science Quarterly, 36(3), 421-458. DOI: 10.2307/2393203.

Barbuto, J. E. Jr., \& Wheeler, D. W. (2006). Scale development and construct clarification of servant leadership. Group \& Organization Management, 31(3), 300-326. DOI: $10.1177 / 1059601106287091$

Barnes, A. C. (2015). Servant leadership for higher education. Journal of College and Character, 16(2), 131-133. DOI: 10.1080/2194587X.2015.1024798

Basit, A., Sebastian, V., \& Hassan, Z. (2017). Impact of leadership style on employee performance (A cast study on a private organisation in Malaysia). International Journal of Accounting \& Business Management, 5(2), 112-130. DOI: 24924/ijabm/2017.11/v5.iss2/112.130

Bavik, A., Bavik, Y. L., \& Tang, P. M. (2017). Servant leadership, employee job crafting, and citizenship behaviors: A cross-level investigation. Cornell Hospitality Quarterly, 58(4), 364-373. DOI: $10.1177 / 1938965517719282$

Bayram, P., \& Zoubi, K. (2020). The effect of servant leadership on employees' self-reported performance: Does public service motivation play a mediating explanatory role? Management Science Letters, 10, 1771-1776. DOI: 10.5267/j.msl.2020.1.002

Bennett, L. (2018, August 28). Your best employees are leaving. But is it personal or practical? Retrieved from: https://rlc.randstadusa.com/press-room/press-releases/your-bestemployees-are-leaving-but-is-it-personal-or-practical

Brohi, N. A., Jantan, A. H., Qureshi, M. A., Jaffar, A. R., Ali, J., \& Ab Hamid, K. (2018). The impact of servant leadership on employees' attitudinal and behavioural outcomes. Cogent Business \& Management, 5(1), 1542652. DOI: 10.1080/23311975.2018.1542652

Byrne, B. M. (2016). Structural Equation Modeling with AMOS: Basic concepts, applications, and programming. New York, NY: Routledge.

Cepeda-Carrion, G., Cegarra-Navarro, J. G., \& Cillo, V. (2019). Tips to use partial least squares structural equation modeling (PLS-SEM) in knowledge management. Journal of Knowledge Management, 23(1), 67-89. DOI: 10.1108/JKM-05-2018-0322

Chan, T. J., Wong, E. Z. Y., \& Wok, S. (2017). Predicting factors of job satisfaction through organisational culture: A case of Malaysian private learning institution. Jurnal Komunikasi: Malaysian Journal of Communication, 33(3), 37-54. DOI: 10.17576/JKMJC-2017-3303-03

Che Nawi, N., Ismail, M., Ibrahim, M. A. H., Raston, N. A., Zamzamin, Z. Z., \& Jaini, A. (2016). Job satisfaction among academic and non-academic staff in public universities in Malaysia: A review. International Journal of Business and Management, 11(9), 148153. DOI: 10.5539/ijbm.v11n9p148 
Chiniara, M., \& Bentein, K. (2016). Linking servant leadership to individual performance: Differentiating the mediating role of autonomy, competence and relatedness need satisfaction. The Leadership Quarterly, 27(1), 124-141.

DOI:10.1016/j.leaqua.2015.08.004

Choudhary, A. I., Akhtar, S. A., \& Zaheer, A. (2013). Impact of transformational and servant leadership on organizational performance: A comparative analysis. Journal of Business Ethics, 116(2), 433-440. DOI: 10.1007/s10551-012-1470-8

Dansereau, F., Cashman, J., \& Graen, G. (1973). Instrumentality theory and equity theory as complementary approaches in predicting the relationship of leadership and turnover among managers. Organisational Behavior and Human Performance, 10(2), 184-200. DOI: 10.1016/0030-5073(73)90012-3

Davidescu, A. A., Apostu, S. A., Paul, A., Casuneanu, I. (2020). Work flexibility, job satisfaction, and job performance among Romanian employees-Implications for sustainable human resource management. Sustainability, 12, 60-86. DOI: 10.3390/su12156086

De Waal, A., \& Sivro, M. (2012). The relation between servant leadership, organizational performance, and the high-performance organization framework. Journal of Leadership \& Organizational Studies, 19(2), 173-190. DOI: $10.1177 / 1548051812439892$

Dennis, R. S., \& Bocarnea, M. (2005). Development of the servant leadership assessment instrument. Leadership \& Organization Development Journal, 26(8), 600-615. DOI: 10.1108/01437730510633692

Dube, T., Zikhali, W., \& Dube, S. P. (2019). An analysis of the application of servant-leadership model in the educational development programmes of selected non-governmental organizations in Zimbabwe. International Journal of Innovative Business Strategies, 5(2), 332-340.

Erdogan, B., \& Bauer, T. N. (2015). Leader-member exchange theory. International Encyclopaedia of the Social \& Behavioral Sciences, 13, 641-647. DOI: 10.1016/B978-008-097086-8.22010-2

Erdogan, B., \& Enders, J. (2007). Support from the top: Supervisors' perceived organisational support as a moderator of leader-member exchange to satisfaction and performance relationships. Journal of Applied Psychology, 92(2), 321-330. DOI: 10.1037/00219010.92.2.321.

Etikan, I., Musa, S. A., \& Alkassim, R. S. (2016). Comparison of convenience sampling and purposive sampling. American Journal of Theoretical and Applied Statistics, 5(1), 1-4. DOI: 10.11648/j.ajtas.20160501.11

Eva, N., Robin, M., Sendjaya, S., Van Dierendonck, D., Liden, R. C. (2019). Servant leadership: A systematic review and call for future research. The Leadership Quarterly, 30(1), 111132. DOI: 10.1016/j.leaqua.2018.07.004

Eva, N., Sendjaya, S., Prajogo, D., Cavanagh, A., \& Robin, M. (2018). Creating strategic fit: Aligning servant leadership with organizational structure and strategy. Personnel Review, 47(1), 166-186. DOI: 10.1108/PR-03-2016-0064

Ezerman, M. M., \& Sintaasih, D. K. (2018). Effect of servant leadership, trust in leadership on organizational citizenship behavior with interpersonal communications as mediation variables. IOSR Journal of Business and Management, 20(4), 21-30.

Faraz, N. A., Mughal, M. F., Ahmed, F., Raza, A., \& Iqbal, M. K. (2019). The impact of servant leadership on employees' innovative work behaviour-mediating role of psychological 
empowerment. International Journal of Management Science and Business Administration, 5(3), 10-21. DOI: 10.18775/ijmsba.1849-5664-5419.2014.53.1002

Gergen, K. J. (1969). The psychology of behavior exchange. Reading, MA: Addison Wesley Publishing Company.

Gharibvand, S. (2012). The relationship between Malaysian organisational culture, participative leadership style, and employee job satisfaction among Malaysian employees from semiconductor industry. International Journal of Business and Social Science, 3(16), 289-298.

Gold, A. H., Malhotra, A., \& Segars, A. H. (2001). Knowledge management: An organizational capabilities perspective. Journal of Management, 18(1), 185-214.

DOI:10.1080/07421222.2001.11045669

Groves, R. M. (2006). Nonresponse rates and nonresponse bias in household surveys. Public Opinion Quarterly, 70(5), 646-675. DOI: 10.1093/poq/nfl033

Greenleaf, R. K. (1998). Servant leadership: A journey into the nature of legitimate power and greatness. New York, NY: Paulist Press.

Hair, J. F., Hult, G., T. M., Ringle, C. M., \& Sarstedt, M. (2017). A primer on Partial Least Squares Structural Equation Modeling (PLS-SEM). Newbury Park, CA: SAGE Publications, Incorporated.

Hair, J., Risher, J., Sarstedt, M., \& Ringle, C. (2019). When to use and how to report the results of PLS-SEM. European Business Review, 31(1), 2-24. DOI: 10.1108/EBR-11-2018-0203

Hajjah, K. G. (2014). Relationship between servant leadership style and intent to stay among the employees in the municipality of Gaza. International Journal of Business and Social Science, 5(7), 95-101.

Hashim, M., Khan, M. A., \& Adnan, S. (2019). Servant leadership and enhancement of organizational performance. Global Social Sciences Review, 4(1), 117-122. DOI: 10.31703/gssr.2019(IV-I).15

Hee, O. C., Qin, D. A. H., Kowang, T. O., Husin, M. M., \& Ping, L. L. (2019). Exploring the impact of communication on employee performance. International Journal of Recent Technology and Engineering, 8(3S2), 654-658. DOI: 10.35940/ijrte.C1213.1083S219

Henseler, J., Ringle, C. M., \& Sinkovics, R. R. (2009). The use of partial least squares path modeling in international marketing. Advances in International Marketing, 20, 277319. DOI:10.1108/S1474-7979(2009)0000020014

Hernández-Perlines, F., \& Araya-Castillo, L. A. (2020). Servant leadership, innovative capacity and performance in third sector entities. Frontiers in Psychology, 11, 1-15. DOI: 10.3389/fpsyg.2020.00290

Homans. G. C. (1961). Social behavior. New York, NY: Harcourt Brace.

Hussain, T., \& Ali, W. (2012). Effects of servant leadership on followers' job performance. Science, Technology and Development, 31(4), 359-368.

Karatepe, O. M., Ozturk, A., \& Kim, T. T. (2019). Servant leadership, organisational trust, and bank employee outcomes. The Service Industries Journal, 39(2), 86-108. DOI: 10.1080/02642069.2018.1464559

Kazan, H., \& Gumus, S. (2013). Measurement of employees' performance: A state bank application. International Review of Management and Business Research, 2(2), 429441.

Khan, A., Khan, A. U., Zeeshan, M. (2016). Consequences of servant leadership style on employees' motivation (empirical study on private and public sector universities employees). Journal of Applied Environmental and Biological Sciences, 6(5S), 124-138. 
Khuwaja, U., Ahmed. K., Abid, G., \& Adeel, A. (2020). Leadership and employee attitudes: The mediating role of perception of organizational politics. Cogent Business \& Management, 7(1), 1720066. DOI: 10.1080/23311975.2020.1720066

Kouzes, J. M., \& Posner, B. Z. (2003). The leadership challenge: How to make extraordinary things happen in organisations ( $5^{\text {th }} \mathrm{Ed}$.). San Francisco, CA: Jossey Bass.

Latif, K. F., \& Marimon, F. (2019). Development and validation of servant leadership scale in Spanish higher education. Leadership \& Organization Development Journal, 40(4), 499-519. DOI: 10.1108/LODJ-01-2019-0041

Latiff, A., Majid, I. A., \& Mohamad, M. (2017). Exploring servant leadership instrument for social enterprise (cooperative). European Journal of Multidisciplinary Studies, 2(3), 723. DOI: $10.26417 /$ ejms.v4i3.p7-23

Liden, R. C., Wayne, S. J., Liao, C., \& Meuser, J. D. (2014). Servant leadership and serving culture: Influence on individual and unit performance. Academy ofManagement Journal, 57(5), 1434-1452. DOI:10.5465/amj.2013.0034

Liden, R. C., Wayne, S. J., Zhao, H., \& Henderson, D. (2008). Servant leadership: Development of a multidimensional measure and multilevel assessment. Leadership Quarterly, 19(2), 161-177. DOI: 10.1016/j.leaqua.2008.01.006

Lor, W., \& Hassan, Z. (2017). The influence of leadership on employee performance among jewellery artisans in Malaysia. International Journal of Accounting \& Business Management, 5(1), 14-33.

Manzuma-Ndaaba, N. M., Harada, Y., Nordin, N., Abdullateef, A. O., \& Romle, A. R. (2018). Application of social exchange theory on relationship marketing dynamism from higher education service destination loyalty perspective. Management Science Letters, 8, 1077-1096. DOI: 10.5267/j.msl.2018.7.004

Memon, M. A., Ting, H., Cheah, J. H., Thurasamy, R., Chua, F., \& Cham, T. H. (2020). Sample size for survey research: Review and recommendations. Journal of Applied Structural Equation Modeling, 4(2), i-xx.

Mensah, J. K. (2015). A "coalesced framework" of talent management and employee performance. International Journal of Productivity and Performance Management, 64(4), 544-566. DOI: 10.1108/IJPPM-07-2014-0100

Muchlas, M. (2014). Perilaku organisasi. Yogyakarta: Gajah Mada University Press.

Muhtasom, A., Mus, H. A. R., Bijang, J., \& Latief, B. (2017). Influence of servant leadership, organisational citizenship behaviour on organisational culture and employee performance at Star Hotel in Makassar. International Journal of Education and Research, 5(10), 71-88.

Muller, R., Smith, E., Lillah, R. (2018). Perceptions regarding the impact of servant leadership on organisational performance in the Eastern Cape. International Journal of Business and Management Studies, 10(1), 46-62.

Khan, I. U., \& Nawaz, A. (2016). The leadership styles and the employee performance: A review. Gomal University Journal of Research, 32(2), 144-150.

Nawoselng'ollan, D., \& Roussel, J. (2017). Influence of leadership styles on employees' performance: A study of Turkana County, Kenya. International Journal of Business and Social Science, 8(7), 82-98.

Neves, P., \& Eisenberger, R. (2012). Management communication and employee performance: The contribution of perceived organisational support. Human Performance, 25(5), 452-464. DOI: 10.1080/08959285.2012.721834 
Insan, N. A. (2020). The effect of servant leadership on employee performance with organizational culture and work involvement as the mediators. International Journal of Advanced Science and Technology, 29(4), 2008-2024.

Otero-Neira, C., Varela-Neira, C., \& Bande, B. (2016). Supervisory servant leadership and employee's work role performance: A multilevel mediation model. Leadership \& Organization Development Journal, 37(7), 860-881. DOI: 10.1108/LODJ-11-2014-0230

Parolini, J. L. (2004). Effective servant leadership: A model incorporating servant leadership and the competing values framework. Retrieved from https://www.regent.edu/acad/global/publications/sl_proceedings/2004/parolini_eff ective_servant.pdf

Podsakoff, P. M., MacKenzie, S. B., Lee, J. Y., \& Podsakoff, N. P. (2003). Common method biases in behavioral research: A critical review of the literature and recommended remedies. Journal of Applied Psychology, 88(5), 879-903. DOI: 10.1037/00219010.88.5.879.

Rashid, M., Tasmin, R., Qureshi, M. I., Shafiq, M. (2017). Relationship of servant leadership with employee in-role and extra-role performance in GLC's of Malaysia. City University Research Journal, Special Issue, 88-95.

Rigdon, E. E. (2016). Choosing PLS path modeling as analytical method in European management research: A realist perspective. European Management Journal, 34(6), 598-605. DOI: 10.1016/j.emj.2016.05.006

Riquelme, H. E., Rios, R. E., \& Gadallah, A. S. (2020). The influence of servant leadership on an organization's serving-driven capabilities in a Kuwaiti bank environment. International Journal of Bank Marketing, 38(3), 692-717. DOI: 10.1108/IJBM-08-2019-0280

Roopa, S., \& Rani, M. S. (2012). Questionnaire designing for a survey. The Journal of Indian Orthodontic Society, 46(4), 273-277. DOI: 10.5005/jp-journals-10021-1104

Saleem, S., \& Amin, S. (2013). The impact of organisational support for career development and supervisory support on employee performance: An empirical study from Pakistani academic sector. European Journal of Business \& Management, 5(5), 194206.

Saleem, F., Zhang, Y. Z., Gopinath, C., \& Adeel, A. (2020). Impact of servant leadership on performance: The mediating role of affective and cognitive trust. SAGE Open, 1-16. DOI: $10.1177 / 215824401990056$

Sani, M. K. J. A., Endin, M. Z., Masrek, M. N., Sahid, N. Z., Baba, J., \& Kamis, Y. (2016). Integrity and employee performance: The experiences of public library leaders. Journal of Southeast Asian Research, 1-15. DOI: 10.5171/2016.452256

Searle, T. P., \& Barbuto, J. E. (2010). Servant leadership, hope, and organisational virtuousness: A framework exploring positive micro and macro behaviors and performance intact. Journal of Leadership \& Organisational Studies, 18(1), 107-117. DOI: $10.1177 / 1548051810383863$

Sekaran, U., \& Bougie, R. (2016). Research methods for business: A skill building approach ( $7^{\text {th }}$ Ed.). New Jersey, NJ: John Willey and Sons, Inc.

Shmueli, G., Sarstedt, M., Hair, J. F., Cheah, J. W., Ting, H., Vaithilingam, S., \& Ringle, C. M. (2019). Predictive model assessment in PLS-SEM: Guidelines for using PLSpredict. European Journal of Marketing, 53(11), 2322-2347. DOI: 10.1108/EJM-02-2019-0189

Sihombing, S., Astuti, E. S., Al Musadieq, M., Hamied, D., \& Rahardjo, K. (2018). The effect of servant leadership on rewards, organisational culture and its implication for 
employees' performance. International Journal of Law and Management, 60(2), 505516. DOI: 10.1108/IJLMA-12-2016-0174

Simamora, P., Sudiarditha, I. K., \& Yohana, C. (2019). The effect of servant leadership on employee performance with employee engagement and organizational citizenship behavior (OCB) as a mediation variable in Mandiri Inhealth. International Journal on Advanced Science, Education, and Religion, 2(3), 13-25. DOI: 10.33648/ijoaser.v2i2.36

Spears, L. (2004). Practicing servant leadership. Leader to Leader, 34, 7-11.

Spector, P. E. (1985). Measurement of human service staff satisfaction: Development of the job satisfaction survey. American Journal of Community Psychology, 13(6), 693-713. DOI: 10.1007/BF00929796

Su, W., Lyu, B., Chen, H., \& Zhang, Y. (2020). How does servant leadership influence employees' service innovative behavior? The roles of intrinsic motivation and identification with the leader. Baltic Journal of Management, 15(4), 571-586. DOI: 10.1108/BJM-09-2019-0335

Sun, J. M., \& Wang, B. (2009). Servant leadership in China: Conceptualisation and measurement. In W. H. Mobley, Y. Wang \& M. Li (Ed.), Advances in Global Leadership, 5, 321-344. DOI: 10.1108/S1535-1203(2009)0000005017

Sydney, A. (2019). Half of employees quit due to poor relationship with their boss. Retrieved from https://www.thehrdirector.com/business-news/people-science/half -employees-quit-due-poor-relationship-boss-7252019/

Tehseen, S., Ramayah, T., \& Sajilan, S. (2017). Testing and controlling for common method variance: A review of available methods. Journal of Management Sciences, 4(2), 146175. DOI: $10.20547 /$ jms.2014.1704202

Thompson, K., \& Webber, J. K. (2016). Leadership best practices and employee performance: A phenomenological telecommunication industry study. Global Journal of Business Research, 10(1), 41-54.

Tjosvold, D., Yu, Z. Y., \& Hui, C. (2004). Team learning from mistakes: The contribution of cooperative goals and problem-solving. Journal of Management Studies, 41(7), 12231245. DOI:10.1111/j.1467-6486.2004.00473.x

Tuan, L. T. (2017). Knowledge sharing in public organizations: The roles of servant leadership and organizational citizenship behavior. International Journal of Public Administration, 40(4), 361-373, DOI: 10.1080/01900692.2015.1113550

Van Dierendonck, D. (2011). Servant leadership: A review and synthesis. Journal of Management, 37(4), 1228-1261. DOI:10.1177/0149206310380462

Wahyu, A., Tentama, F., \& Sari, E. Y. D. (2019). The role of servant leadership and organizational climate on organizational citizenship behavior with job satisfaction as mediator. International Journal of Scientific \& Technology Research, 8(10), 1134-1141.

Wheeler, D. W. (2012). Servant leadership in higher education: Principles and practices. New York, NY: John Wiley and Sons.

Wilkins, S., Butt, M. M., \& Annabi, C. A. (2017). The effects of employee commitment in transnational higher education: The case of international branch campuses. Journal of Studies in International Education, 21(4), 295-314. DOI: 10.1177/1028315316687013

Wong, P. T., \& Page, D. (2000). Servant leadership: An opponent-process model and the revised servant leadership profile. Virginia Beach, VA: Servant Leadership Research Roundtable. 
Ye, Y., Lyu, Y., \& He, Y. (2019). Servant leadership and proactive customer service performance. International Journal of Contemporary Hospitality Management, 31(3), 1330-1347. DOI: 10.1108/IJCHM-03-2018-0180

Yukl, G., Gordon, A., \& Taber, T. (2002). A hierarchical taxonomy of leadership behavior: Integrating a half century of behavior research. Journal of Leadership Organisational Studies, 9(1), 15-32. DOI: 10.1177/107179190200900102

Zarim, Z. A., \& Zaki, H. O. (2016). Ethics and integrity in building employees' perceptions. Management Studies, 4(3), 131-137. DOI: 10.17265/2328-2185/2016.03.004 